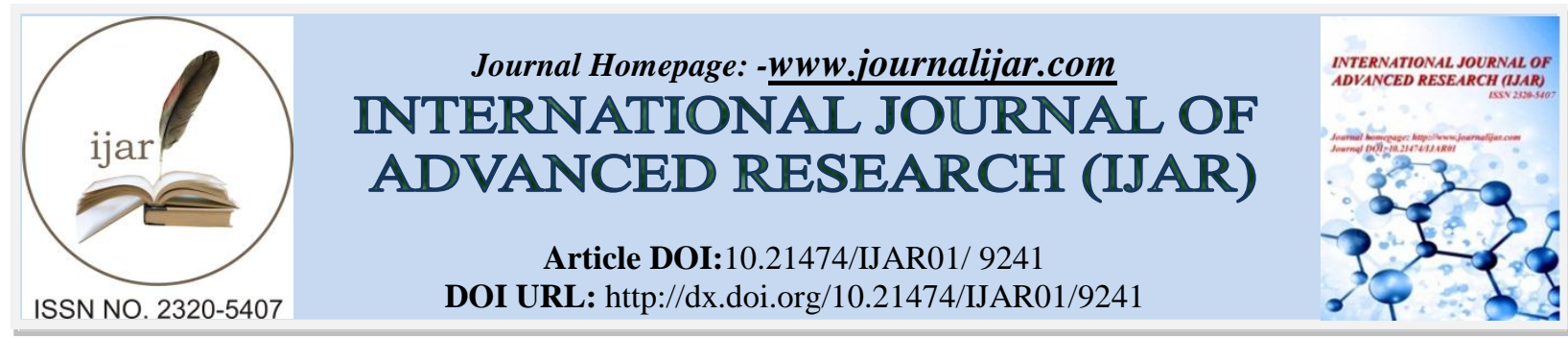

RESEARCH ARTICLE

\title{
A STUDY ON FINANCIAL PERFORMANCE OF PUBLIC SECTOR BANKS IN AFGHANISTAN USING CAMEL MODEL.
}

\begin{abstract}
Abdul Sami Sharifi.
MBA Student at Chandigarh University.

Manuscript Info

Manuscript History

Received: 08 April 2019

Final Accepted: 10 May 2019

Published: June 2019

Key words:-

CAMEL approach, Pubic Sector Banks,

Financial Performance.

\section{Abstract}

This study attempts to measure the financial performance of public sector banks in Afghanistan for the period of four years (2014 to 2017) using CAMEL approach. CAMEL stands for Capital Adequacy, Asset Quality, Management Soundness, Earning Quality and Liquidity

To accomplish the task, I have chosen three banks out of four banks operating in public sector in Afghanistan. Financial statements of the selected banks are then examined and evaluated for the period of 4 years (from 2014 to 2017) with the help of some ratios.

Nowadays, banking sector in Afghanistan is facing the problem of default culture, which is the result of inefficient performance of most banks. The performance of the banks are dependent more on the management's ability in formulating strategic plans and the efficient implementation of these plans.

The findings of this study can be very helpful for the management of the banks to improve their financial performance and formulate such policies that help to improve the overall financial performance. This study also identify factors that influence performance of banks.
\end{abstract}

Copy Right, IJAR, 2019,. All rights reserved.

\section{Introduction:-}

Bank is a financial institution that contributes to the economy development of a country largely. Smooth and efficient functioning of a bank is very vital for financial stability. Bank is an institution where deposits of public are accepted and these deposits constitute major part of national money supply.

Financial statements such as balance sheet and income statements of a bank need to be carefully diagnosed and investigated and the results of investigation then can be used by the bank management for making better decisions related to the banking activities. Financial statements of a bank only depicts results of the banking activities, it does not explain any reasons if there is any undesirable performance in business activities. Therefore, it is very vital to analyze and evaluate financial statements of a bank periodically.

In this study, I have evaluated financial performance of three public sector banks (New Kabul Bank, Pashtany Bank and Bank-e-Millie Afghan) for the period (2014-2017). There are many tools and approaches developed by financial expert for analyzing financial performance of a bank. I have used one of effective and most commonly used technique i.e. CAMEL model. In this model of analyzing financial performance, financial performance is studied from different angles using some financial ratios. 
Capital (C) CAR is a ratio used for measuring capital adequacy of a bank. This can be done by comparing bank's equity capital to its total assets. Capital Adequacy Ratio helps to get trust of depositors and used to ensure efficient growth and stability of financial systems all around the globe. Capital Adequacy Ratio can be calculated by dividing Total Equity Capital of a bank to its Total Assets. The resulting value is in terms of absolute value to convert it into relative form; we simple multiply it to 100 .

Asset (A) Assets Quality is another aspect in CAMEL approach. This aspect is used to measure quality of assets in banks. For doing so, the total amount of advances and loans given to customers and the total value of assets are required. Assets Quality can be calculated by dividing loans and advances to total assets. Assets Quality Ratio is named as loan and advances to total assets.

Management (M) it is a measure used to show level of efficiency and soundness of management in a bank. Different ratios are available for finding out management soundness and efficiency of a bank. In this particular paper, I have used the most common one, which is Total Interest Income to Total Income Ratio.

Earning (E) Earning Quality is another aspect in CAMEL method. There are many ratios used to evaluate earning quality of a bank. in the paper, I am using three ratios to measure the earning quality of New Kabul Bank: Return on Assets (ROA), Net Interest Margin and Net Profit Margin.

For calculating Return on Assets (ROA), value of Net Profit after Tax and Total Assets are needed. We can get ROA by dividing Net Profit after Tax to Total Assets.

The value of Net Interest Income and Total Assets are required for finding Net Interest Margin. Division of Net Interest Income by Total Assets will provide us Net Interest Margin. And Net Profit Margin can be calculated by dividing value of Profit after Tax to value of Total Loans and Advances.

Liquidity (L) Liquidity ratio gauges a bank's capability to meet its short-term obligations. Generally, the higher the liquidity ratio means the firm is safe and able to meet its short-term obligations on time. There are different ratios, which are used to find out strength of banks to meet its financial short-term obligations on time. Here, in this paper, Loan to Deposit Ratio and Customer Deposit to Total Asset Ratio are discussed for evaluating the liquidity position of Afghanistan's Public Sector Banks.

It is very vital for both the bank management and other stakeholders to know the level of the financial performance of the bank as it helps in making investment decisions for potential investors; formulating and executing policies regarding to finances for managers. In this paper, financial performance of the banks are examined in a quantitative manner and then comparison is made between public sector banks. The relevant data in this paper is collected and evaluated with care so as to generate a true results reflecting real image of financial performance of public sector banks in Afghanistan.

\section{Problem Statement}

In the age of globalization, banking sectors play a vital role to the development of economy of any country. In fact, banks, as a financial institution contribute toward economy stability for a long time. Bank is a financial institution that accept funds from the public and places them in financial assets such as deposits loans etc. in today's world functioning area of banking sectors are not limited to a specific geographical area. Its transactions are done beyond the limits of a country. Therefore, it is very important for stakeholders to know about the financial performance and the financial position of the banks. For this purpose, financial analysts, analysis financial statements of the banks, and the tools that is mostly used and is very effective for analyzing the financial statements is CAMEL approach.

\section{Objective of the Study}

The main objective of this study is to evaluate financial performance of Public Sector Banks in Afghanistan using CAMEL approach.

Some other specific objectives are:

1. To compare financial performance of public sector banks in Afghanistan.

2. To figure out in which aspect the bank is not performing well.

3. To compare financial performance of the bank among different selected years. 
4. To give some suggestions for public sector banks Bank for better improving its financial activities.

\section{Significance of the Study}

This study would help the bank management, bank customers and other potential investors to get knowledge about financial performance and financial position of the bank. Moreover, this research paper evaluate performance of the bank in depth from different angle using CAMEL approach. In addition, this paper is being done with the intention of getting researchers attention and their discussion regarding to financial performance of New Kabul Bank and its effect to the economy growth and stability of the country. This study also discuss the factors that has affection to the performance of the bank and these factors can be used positively by bank management for better and efficient functioning of banking activities. the study also can be considered as a guidance and motivation for upcoming researchers.

\section{Theoretical Background and Review of Literature}

Financial researchers from different countries have conducted many of research on financial performance of banks. These researchers have so far developed and used several tools and techniques to study the financial performance of different organizations-banking banking and non-banking sectors, public and private banks in various countries.

Majority of researchers have gone with secondary data that were convenient for them to get relevant data from secondary data sources published by banks or other organizations. Almost, all banks in all countries are needed to publish their financial reports to act transparency in banking sectors.

The data collected from financial reports are then studied and analyzed by researchers using different tools or methods to examine financial performance of banks. Some of the most commonly used tools for calculating level of financial performance of banks are: ratio analysis, comparative financial statements and common size statements. Ratio analysis is most commonly used tool for studying level of financial performance of banks. In this method, elements in financial statements are presented and calculated in terms of ratios and then compared with one another. The objective of ratio analysis is to give better picture of banks' management efficiency, financial soundness and position. Comparative financial statements compare bank financial statements with previous years financial statements. This is good for knowing level of changes in financial performance of the banks. Comparative financial statements are also utilized to compare one bank's financial statements with other banks

Noor Rahman Tahiri (2018) studies financial performance of Da Afghanistan Bank DAB during 2015 and 2016. He has done so suing financial ratios analysis technique. The paper shows that, financial performance of Da Afghanistan Bank in 2016 has decreased as compare to that of 2015. The paper points out three main factors that caused in inefficiency of bank in 2016. The first factor is increase in commission and licensing fees by the management of Da Afghanistan Bank. The second cause in low performance of the bank is due to huge changes in foreign exchange rate (Forex) this had badly impact on performance of Da Afghanistan Bank in 2016. Moreover, the last factor could be the overall changes in reserve of the bank in decreasing manner.

Riyad Mahmud (2013) analyzed financial statements of Sonali Bank Limited. He has done so with the help of financial ratio analysis (FRA). Financial statement analysis is a technique utilized by bank management and individual potential investors. The study indicates that the present picture of where budgetary instability is endemic and monetary instinct is getting to be prevalent with regards to contribution, the sound analysis of finance explanation is a standout amongst the most essential components in the fundamental analysis process. Meanwhile, the huge measure of numbers in an organization's financial reports can be confounding and scaring to numerous financial specialists. Be that as it may through financial ratio analysis, he attempts to work with these numbers in a composed manner and exhibited them in a outlining structure effectively reasonable to both administration and potential investors.

Esmatullah Mohammady (2019) conducted a research on financial performance of both private and public sector banks in Afghanistan. He has used CAMEL approach as a quantitative financial tool for evaluating financial performance of banks in Afghanistan. The findings of the study states that, financial performance of banks are based on different parameters, such as Capital Adequacy Ratio, Asset Quality Ratio, Management Soundness, Earing Quality and Liquidity Analysis. Based on Capital Adequacy Ratio, private sector banks are better performing than public sector banks. As per Asset Quality Ratio, private banks are outperforming public banks. According Management Soundness parameter, private sector banks are still performing better that public sector banks. Based on Earning Quality, public banks are located in a better position and based on Liquidity Analysis, again private 
sector banks are good. In general, the study has concluded that, private sector banks are in better financial position in Afghanistan as compare to public sector banks.

Medhat Tarawneh (2006) conducted a research to compare financial performance of banking sectors in Oman during 1999-2003. In his study, five Omani commercial banks with more than 269 branches were financially analyzed. The main finding of the study was that, the better profitability performance does not always mean that the banks are having higher total capital, deposits, credits, or assets; rather it depends to a great extends to the efficiency of management to take better decisions to enhance financial position and performance of the bank.

Srinivasan, P. and Britto, J. (2017) evaluated the financial performance of selected Indian commercial banks for the period from 2012/13 to 2016/17. In this study, it was found that, private sector banks are outperforming public sector banks. The study also finds that, the increasing level of non-performing asset (NPAs) is the most challenging effort forced by the Indian banking system more specifically public sector banks. This study suggests that, public sector banks need to take some vital steps towards enhancing their liquidity and solvency position to increase their profitability. In addition, the private sector banks should improve their turnover and solvency position to increase their profits.

Mustafa Hassan Mohammad Adam (2014) conducted a research to evaluate the financial performance of Erbil Bank for investment and finance for the period 2009-2013. To do so, he has used financial ratio analysis. The study found that, the ROA of the bank were negatively influenced by size of the bank and operational efficiency is also influenced with ROA in negative manner. The study can be used by bank managers and other potential investors in their decision-making towards signifying efficiency of managers, investment as well as improving financial performance of the banks. The study also suggests some efforts that could be followed by bank managers to ensure soundness of their operations.

Mabwe Kumbirai and Robert Webb (2010) analyzed the performance of South Africa's commercial banking sector for the period of 2005 to 2009 . For the study, they have used financial ratio to investigate profitability, liquidity and credit quality performance of five major commercial banks in South Africa. The study found that, the overall performance improved to a great extend in first two years of investigation. At the onset of the global financial crisis in 2007, considerably changes in trend occurred reaching highest during 2008-2009. This causes in decreasing profitability, less liquidity and lower credit quality in the South African banking sector.

Alemu and Aweke (2017) investigated the performance of commercial private banks of Ethiopia using CAMEL rating approach for the period from 20017 to 2016 . The study outlined the following major findings:

1. In terms of capital adequacy indicators, WEGAGEN and NIB bank ranked first. DB got the last position.

2. Regarding to asset quality, UB got the first position and WEGAGEN placed at the bottom.

3. In case of management quality measures, UB bank scored top position, AIB held the last position.

4. Concerning earning ability, NIB performed well and stood at the first position.

5. In terms of liquidity, DB and UB outperformed whereas, WEGAGEN bank stood last.

6. Considering overall composite rating of CAMEL approach, NIB performed very well and took the first position whereas, AIB and BOA banks maintained last position.

K. P. Venugopala Rao and Farha Ibrahim (2017) the study is conducted to investigate financial performance of IDBI bank. The study found that, the bank is in a better solvency position and the employment of its assets are in trends with the industry average. Shareholders fund and the CASA is not fully utilized. Net Profit Margin of RDBI bank shows the profitability of the bank is lower below the industry average therefore, attention need t'o be paid in efficiency of the operations. The study also states that the bank needs to provide cheaper funds to its customers this can lead to higher financial performance. The ROA of RDBI bank indicates the decreasing trend as to compare with the industry-this means that the bank should take steps towards effectively utilization of assets.

Jeevan Jayant Nagarkar (2015) analyzed financial performance of banks in India. The study found that it is important to get faith and trust of depositors and it is a key of every bank's success. The study also says that nonperforming assets need to be reduced through credit appraisal process. The banks need to rely more on deposit money rather than borrowing it. The finding also indicates, the overall deposits of commercial banks have declined and credit worthiness has gone down. 
Dr. M Selvam (2013) investigates financial performance of Kenyan commercial banks using Data Envelopment Analysis (DEA). The study points out the following findings: there was considerably changes in performance of banking sector in Kenya. The changes can better seen in public sector banks comparing with private sector banks. Shares of public sector banks are moving up and that of private banks going down. In overall, performance of public sector banks are better performing the domestic private banks.

Ch. Balaji (2016) conducted a comparative study on financial performance of selected public and private sector banks in India during 2011 to 2015. The period covers financial sector reforms, which brought positive changes in the banking industry. The finding indicates that, profitability was gone up for both public and private sector banks but the rate of growth is higher for private sector banks. The study suggests the public sector banks need to reform their strategies by considering their strength and weakness and the type of market they are operating in. in the other hand, private sector banks must consider societal aspects in order to maintain balanced growth for the industry and the nation.

Malihe Rostami (2015) analyzed banking industry using CAMELS' Rating model. CAMELS' Rating model is best approach for finding out the financial strength and weakness of banking industry. It also assist managers to control and analyze financial data and its position in the industry. Foremost angle of CAMELS is to compare a company with other internal and external industries.

\section{Methodology:-}

The study covers three public sector banks in Afghanistan: Pashtany Bank, New Kabul Bank and Bank-e-Millie Afghan. To accomplish the task, the data for this study was gathered from banks' financial statements for the period (2014 to 2017). For evaluating the financial performance of the banks, I have used one of most effective and common tools i.e. CAMEL approach.

Table 1:-indicates CAMEL model and ratios used for this study.

\begin{tabular}{|r|r|}
\hline CAMEL & Ratios \\
\hline Capital Adequacy & Equity capital to Total Assets=Equity Capital/Total Asset \\
\hline Assets Quality & Loans and Advances to Total Assets=Loan \& Advances/Total Asset \\
\hline Management Soundness & Interest Income to Total Income=Interest Income/Total Income \\
\hline Earnings & Return on Asset (ROA)=Net Profit after Tax/Total Assets \\
\cline { 2 - 2 } & Net Interest Margin=Net Interest Income/Total Assets \\
\cline { 2 - 2 } & Net Profit Margin=Profit after Tax/Total Loans and Advances \\
\hline Liquidity & Loan to Deposit=Total Loan/Total Deposit \\
\cline { 2 - 2 } & Deposits to Total Assets=Total Deposits/Total Assets \\
\hline
\end{tabular}

\section{Analysis and Results:-}

\section{Capital Adequacy Ratio}

Table. 2 and chart 1 shows that, based on CAR, Bank-e-Millie is outperforming. Among the public sector banks in Afghanistan, New Kabul Bank has worst performance in case of CAR. The average value for the three banks is 7.11 which is not too bad.

Table 2:-Capital Adequacy of Banks (Total Equity to Total Asset)

\begin{tabular}{|c|c|c|c|c|c|}
\hline Banks & 2014 & 2015 & 2016 & 2017 & Avg. Value \\
\hline Pashtany Bank & 5.98 & 4.48 & 10.15 & 9.05 & 7.42 \\
\hline New Kabul Bank & -17.29 & -19.54 & 3.51 & 5.39 & -6.98 \\
\hline Bank-e-Millie Afghan & 22.76 & 18.18 & 22.73 & 19.89 & 20.89 \\
\hline Avg. CAR & \multicolumn{5}{|c|}{$\mathbf{7 . 1 1}$} \\
\hline
\end{tabular}

Chart 1. Capital Adequacy Ratio (Total Equity to Total Asset) 


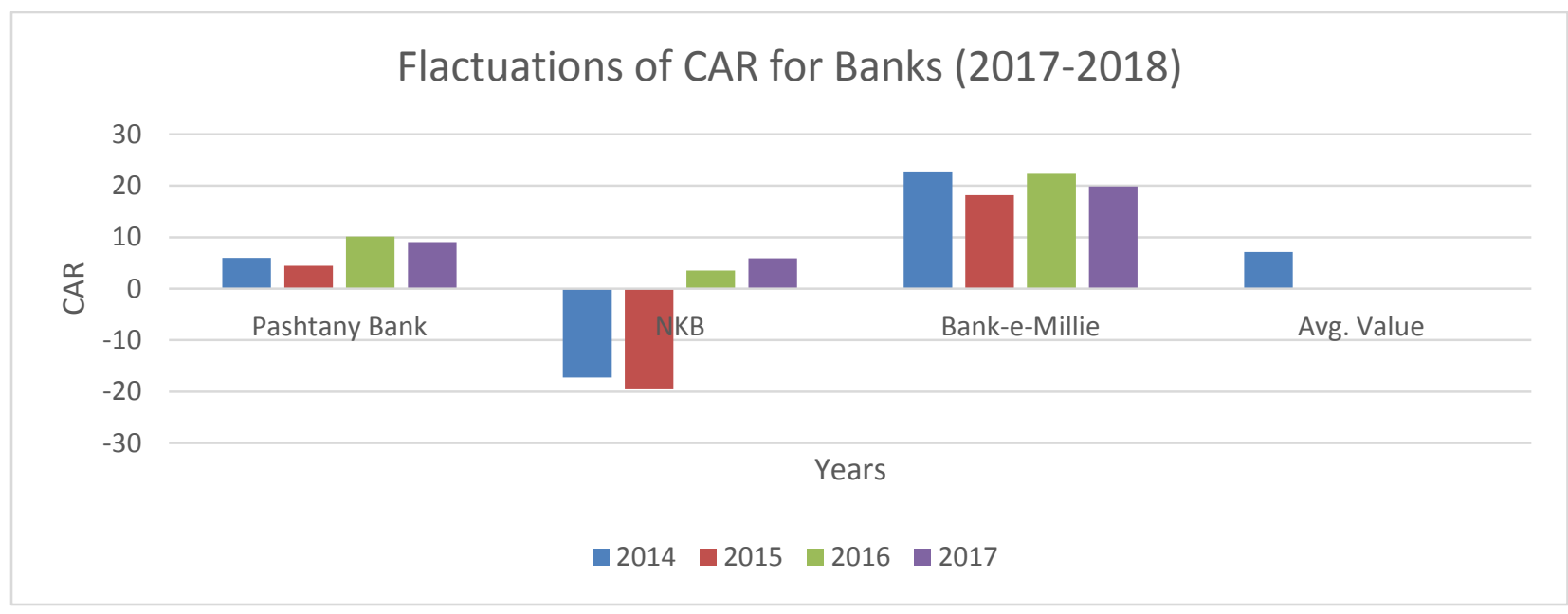

Table 3. depicts banks rankings base of Capital Adequacy Ratio

Table 3:-Shows ranking of banks based on Capital Adequacy Ratio

\begin{tabular}{|c|c|c|}
\hline Ranks & Bank & Average Value \\
\hline 1 & Bank-e-Millie Afghan & 20.89 \\
\hline 2 & Pashtany Bank & 7.42 \\
\hline 3 & New Kabul Bank & -.6 .98 \\
\hline
\end{tabular}

\section{Asset Quality Analysis}

The following table and chart depicts banks' loans and advances to total asset ratio. Based on this ratio, Bank-eMillie Afghan is the best performer. New Kabul Bank is not giving loans to its customers, so the table is showing 0 for loans and advances to total asset ratio.

Table 4:-Asset Quality of Banks (Loans and Advances to Total Asset)

\begin{tabular}{|c|c|c|c|c|c|}
\hline Banks & 2014 & 2015 & 2016 & 2017 & Avg. Value \\
\hline Pashtany Bank & 5.72 & 0.03 & 0.00 & 0.00 & 1.44 \\
\hline New Kabul Bank & 0.00 & 0.00 & 0.00 & 0.00 & 0.00 \\
\hline Bank-e-Millie Afghan & 8.86 & 8.95 & 7.05 & 6.20 & 7.76 \\
\hline Avg. AQ & \multicolumn{5}{|c|}{3.07} \\
\hline
\end{tabular}

Chart 2:-Asset Quality of Banks (Loans and Advances to Total Asset)

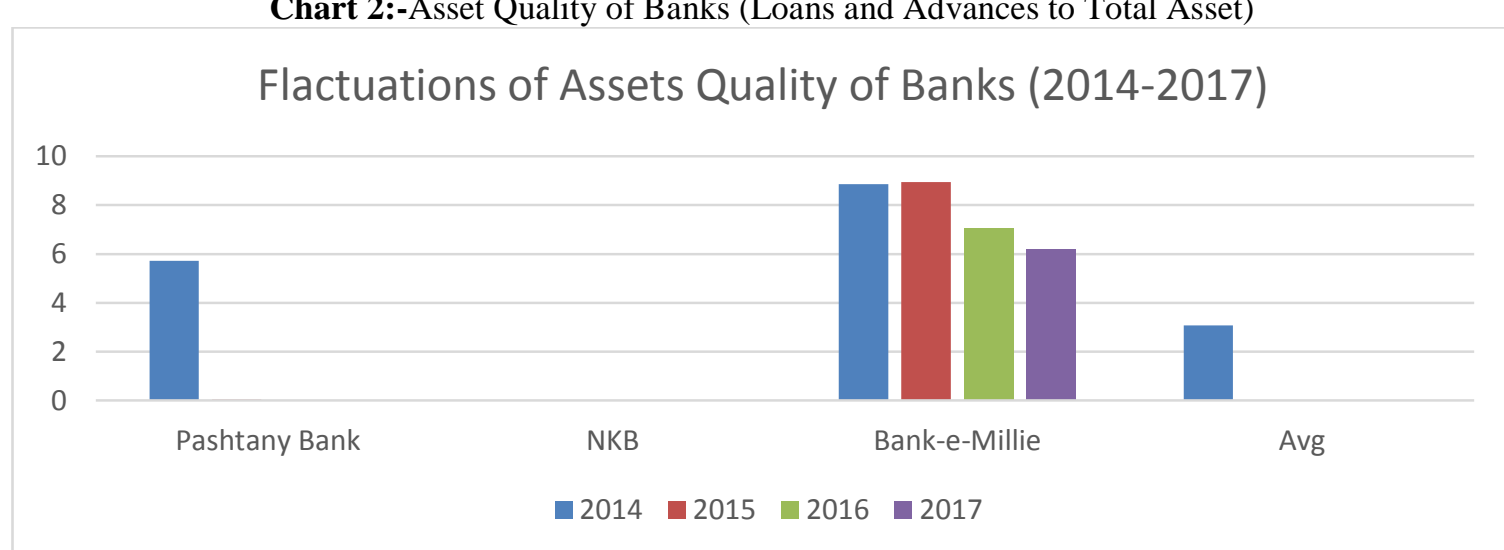

Table 5. indicates banks ranking based on Loans and Advances to Total Asset Ratio 
Table 5:-Ranking of the banks based on Loans and Advances to Total Asset Ratio

\begin{tabular}{|c|c|c|}
\hline Ranks & Banks & Average Value \\
\hline 1 & Bank-e-Millie Afghan & 1.76 \\
\hline 2 & Pashtany Bank & 0.44 \\
\hline 3 & New Kabul Bank & 00 \\
\hline
\end{tabular}

\section{Management Soundness Analysis}

According to Table 6. And chart 3. Among the banks, Bank-e-Millie Afghan is outperforming in case of Total Interest Income to Total Income ratio. That indicates, Bank-e-Millie is best performance in terms of management soundness, on the other hand, New Kabul Bank is showing less efficiency in terms of management soundness. Average ratio of Total Interest Income to Total Income for Afghanistan public sector banks is 37.07.

Table 6:-Management Soundness of Banks (Interest Income to Total Income)

\begin{tabular}{|c|c|c|c|c|c|}
\hline Banks & 2014 & 2015 & 2016 & 2017 & Avg. Value \\
\hline Pashtany Bank & 57.9 & 55.12 & 30.29 & 37.85 & 48.28 \\
\hline New Kabul Bank & 18.22 & 13.88 & 7.45 & 20.40 & 14.99 \\
\hline Bank-e-Millie Afgha & 67.32 & 64.78 & 19.87 & 51.82 & 50.49 \\
\hline Avg. Ratio & $\mathbf{3 7 . 0 7}$ \\
\hline
\end{tabular}

Chart 3:-Management Soundness of Banks (Total Interest Income to Total Income 2014-2017)

\section{Flactuations of Total Interest Income to Total Income}

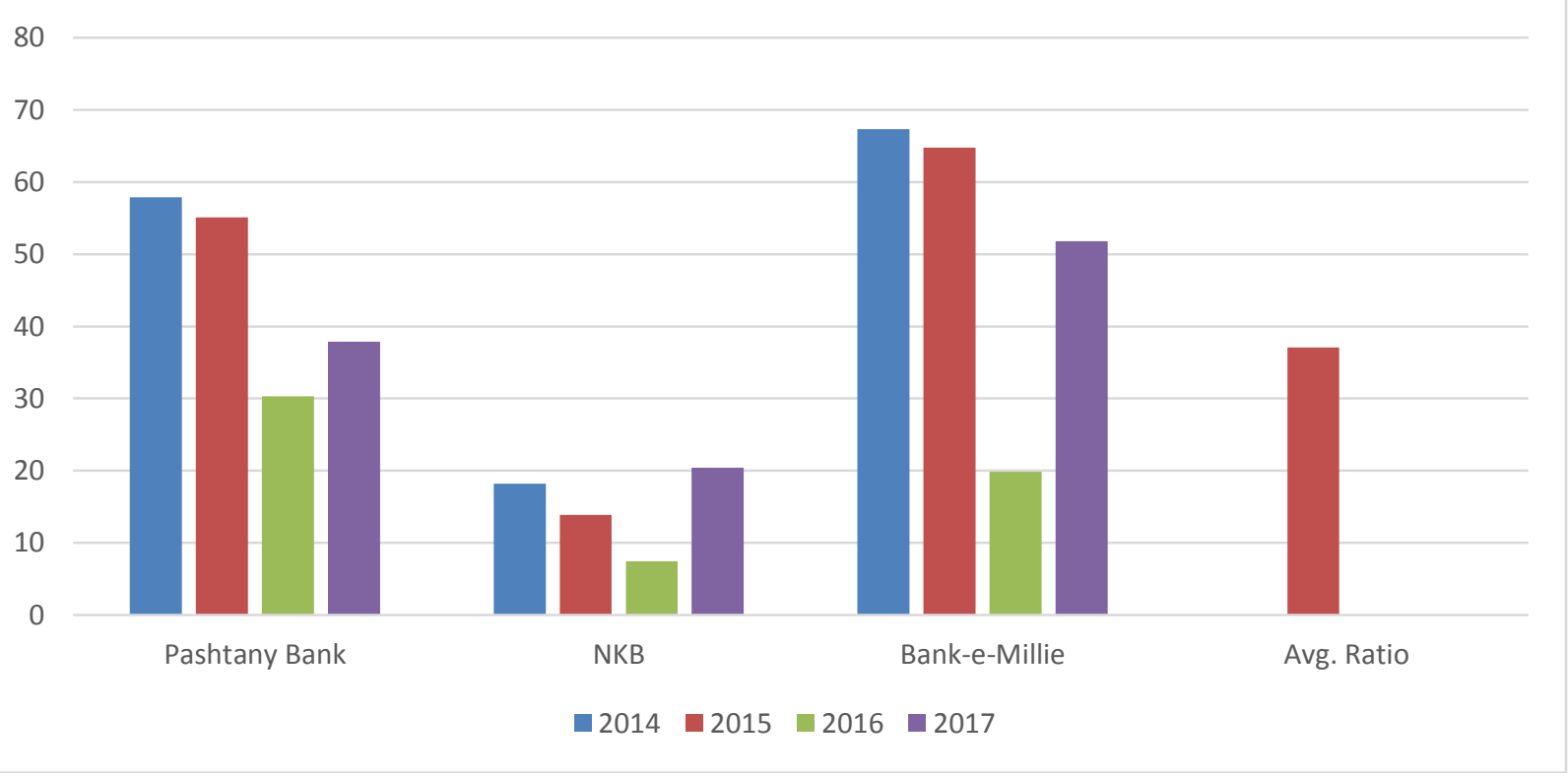

Table 7. Shows ranking of banks in terms of Management Soundness

Table 7:-Ranking of banks base on Management Soundness

\begin{tabular}{|c|c|c|}
\hline Ranks & Banks & Average Ratio \\
\hline 1 & Bank-e-Millie Afghan & 50.49 \\
\hline 2 & Pashtany Bank & 48.28 \\
\hline 3 & New Kabul Bank & 14.99 \\
\hline
\end{tabular}

\section{Earning Quality Analysis}

Better earning quality means better profitability. Three ratios are calculated for determining earning quality of public sector banks in Afghanistan. 


\section{Return on Asset Ratio (RoA)}

The following table and chart indicates RoA. As it can be seen from the figures that, Bank-e-Millie Afghan is highest earning quality with average RoA ratio of 3.23. among the public sector banks in Afghanistan, New Kabul is showing least RoA with average of 0.03 .

Table 8:-Earning Quality: RoA Ratio (Net Profit after Tax to Total Asset)

\begin{tabular}{|c|c|c|c|c|c|}
\hline Banks & 2014 & 2015 & 2016 & 2017 & Avg. RoA \\
\hline Pashtany Bank & 2.34 & -3.10 & 4.03 & 0.13 & 0.85 \\
\hline New Kabul Bank & -1.45 & -0.20 & 0.21 & 1.57 & 0.03 \\
\hline Bank-e-Millie Afghan & 1.20 & 1.98 & 8.79 & 0.94 & 3.23 \\
\hline Avg. RoA for all Banks & \multicolumn{5}{|l}{1.37} \\
\hline
\end{tabular}

Chart 4:-Earning Quality: RoA Ratio

\section{flactuations of RoA (2014-2017)}

10

8

6

4

2014

- $2015 \square 2016 \square 2017$

Table 9. shows ranking banks base on RoA Ratio

Table 9:-Ranking of banks in terms of RoA

\begin{tabular}{|c|c|c|}
\hline Ranks & Banks & Avg. RoA \\
\hline 1 & Bank-e-Millie Afghan & 3.23 \\
\hline 2 & Pashtany Bank & 0.85 \\
\hline 3 & New Kabul Bank & 0.03 \\
\hline
\end{tabular}

\section{Net Interest Margin}

Based on table 10 and chart 5, Bank-e-Millie Afghan has the highest net interest margin with an average of 2.48.

Pashtany Bank's net interest margin is still good as compare to New Kabul Bank. NKB has an average value of 1.12 net interest margin and this bank has the lowest net interest margin among public sector banks in Afghanistan.

Table 10:-Net Interest Margin (Net Interest Income to Total Asset)

\begin{tabular}{|c|c|c|c|c|c|}
\hline Banks & 2014 & 2015 & 2016 & 2017 & Avg. Value \\
\hline Pashtany Bank & 2.30 & 2.45 & 1.69 & 1.05 & 1.87 \\
\hline New Kabul Bank & 1.39 & 1.12 & 0.44 & 1.52 & 1.12 \\
\hline Bank-e-Millie Afghan & 2.88 & 2.72 & 2.28 & 2.03 & 2.48 \\
\hline Average Ratio & $\mathbf{1 . 8 2}$ &
\end{tabular}


Chart 5:-Net Interest Margin (Net Interest Income to Total Asset)

\section{Flactuation of Net Interest Margin (2014-2017)}

3.5

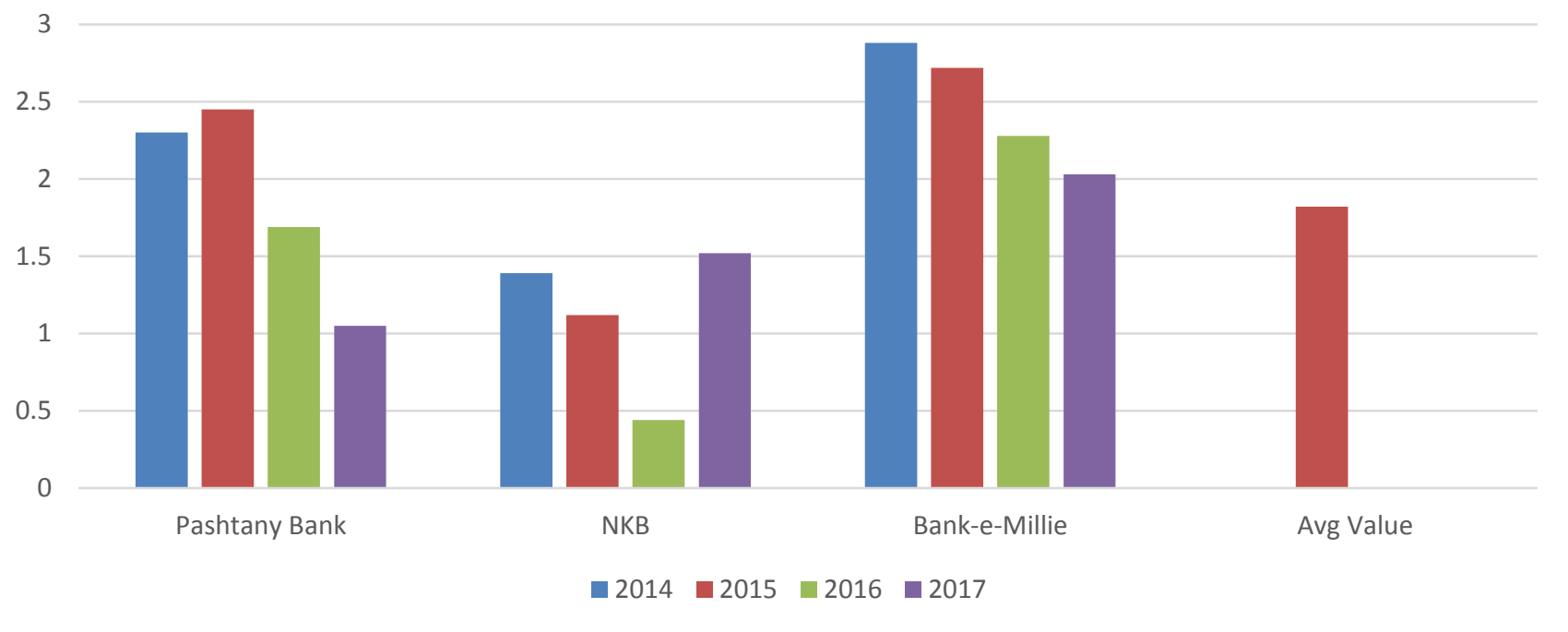

Table 11:-Banks ranking base on Net Interest Margin

\begin{tabular}{|c|c|c|}
\hline Rank & Bank Name & Average Value \\
\hline 1 & Bank-e-Millie Afghan & 2.48 \\
\hline 2 & Pashtany Bank & 1.87 \\
\hline 3 & New Kabul Bank & 1.12 \\
\hline
\end{tabular}

\section{Net Profit Margin}

As it can be seen from table 12. Bank-e-Millie Afghan is outperformer in terms of Net Profit Margin with average value of 43.89. this indicates the highest earning to the bank. Net Profit Margin can not be calculated in New Kabul Bank due to unavailability of loans issued by NKB. Pashtany Bank has the lowest (negative) Net Profit Margin.

Table 12:-Net Profit Margin (Profit after Tax to Loans and Advances)

\begin{tabular}{|c|c|c|c|c|c|}
\hline Banks & 2014 & 2015 & 2016 & 2017 & Avg. Value \\
\hline Pashtany Bank & 4.93 & -11732 & NA & NA & -2923 \\
\hline New Kabul Bank & N/A & N/A & N/A & N/A & 0.00 \\
\hline Bank-e-Millie Afghan & 13.56 & 22.13 & 124.75 & 15.12 & 43.89 \\
\hline Avg. ratio & \multicolumn{5}{|l}{} \\
\hline
\end{tabular}

The following table gives ranking of banks base on Net Profit Margin.

Table 13:-Ranking base of Net Profit Margin

\begin{tabular}{|c|c|c|}
\hline Rank & Bank Name & Average value \\
\hline 1 & Bank-e-Millie Afghan & 43.89 \\
\hline 2 & New Kabul Bank & 0.00 \\
\hline 3 & Pashtany Bank & -2923 \\
\hline
\end{tabular}

\section{Liquidity Analysis}

I have used to ratios for measuring liquidity of the banks. One is Loan to Total Deposit ratio and other one is Customer Deposit to Total Asset ratio. 


\section{Loan to Total Deposit Ratio}

Table 14 and figure 6 describes loan to total deposit ratio. Based on the results, we can say that, Bank-e-Millie Afghan is having the highest loan to total deposit ratio among the public sector banks. In case of NKB, this ratio is not been calculated due to unavailability of loans. In case of Pashtany Bank, the ratio is calculated in 2014 and 2015 and its average loan to total deposit ratio is 1.56. the overall average ratio for all three banks is 3.96.

Table 14:-Liquidity Analysis: Loan to Total Deposit Ratio

\begin{tabular}{|c|c|c|c|c|c|}
\hline Banks & 2014 & 2015 & 2016 & 2017 & Avg. Ratio \\
\hline Pashtany Bank & 6.21 & 0.03 & 0.00 & 0.00 & 1.56 \\
\hline New Kabul Bank & 0.00 & 0.00 & 0.00 & 0.00 & 0.00 \\
\hline Bank-e-Millie Afghan & 11.85 & 11.75 & 9.59 & 8.05 & 10.31 \\
\hline Avg. ratio for all banks & $\mathbf{3 . 9 6}$ \\
\hline
\end{tabular}

Chart 6:-Liquidity Analysis: Loan to Total Deposit Ratio

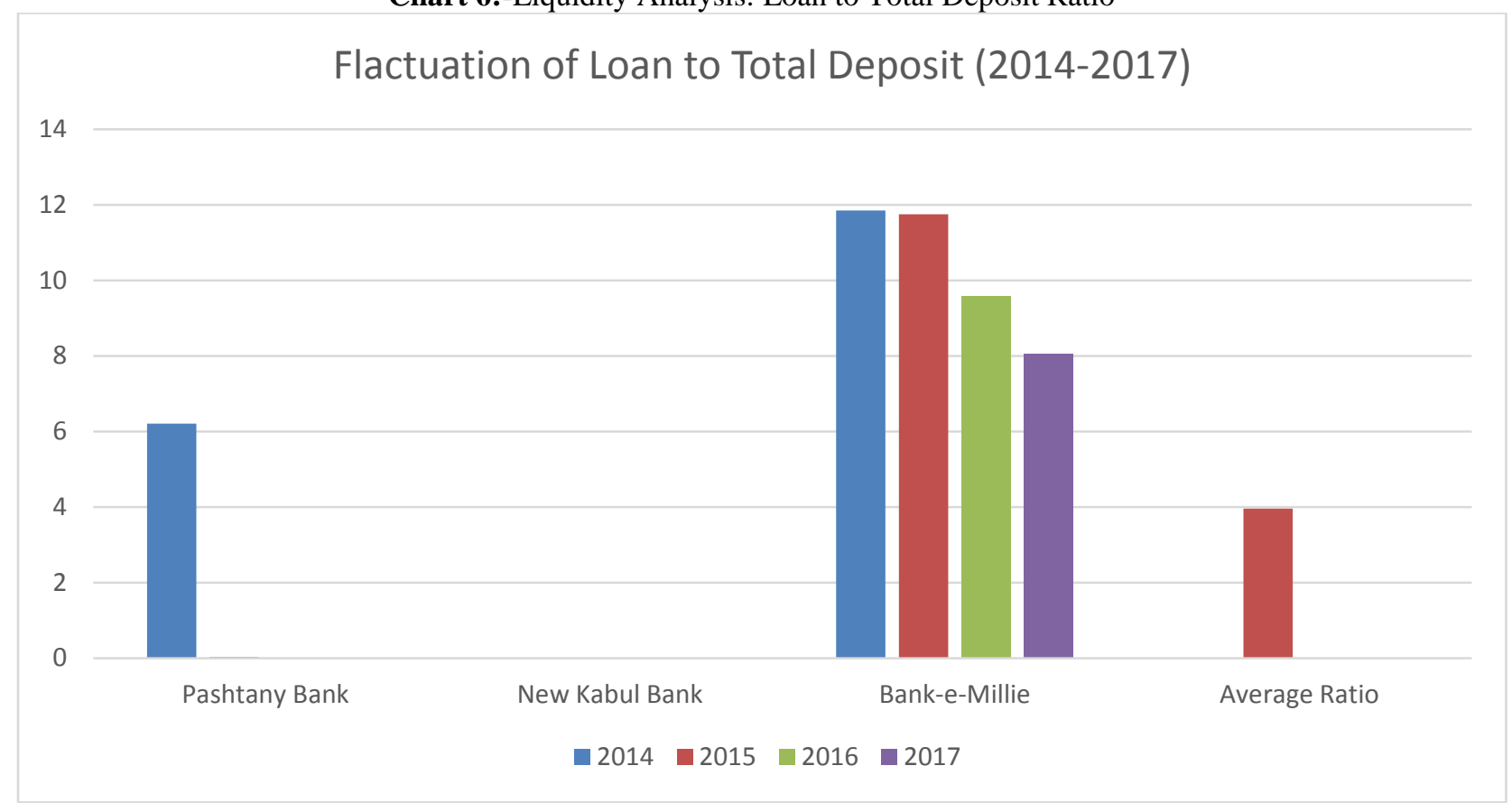

Table 15. shows ranking of banks in terms of Loan to Total Deposit ratio

Table 15:-Banks' ranking base on Loan to Total Deposit Ratio

\begin{tabular}{|c|c|c|}
\hline Ranks & Bank & Avg. ratio \\
\hline 1 & Bank-e-Millie Afghan & 10.31 \\
\hline 2 & Pashtany Bank & 1.56 \\
\hline 3 & New Kabul Bank & 0 \\
\hline
\end{tabular}

\section{Customer Deposit to Total Asset Ratio}

Table 16 and figure 7 depicts banks' customer deposit to total asset ratio for Afghanistan's public sector banks for the period 2014-2017. Based on data in the table, New Kabul bank is outperforming and its average customer deposit to total asset ratio is 102.69. Pashtany bank gets the second position with average value of 89.87 and Banke-Millie is having lower performance in terms of customer deposit to total asset ratio.

Table 16:-Liquidity Analysis: Customer Deposit to Total Asset Ratio

\begin{tabular}{|c|c|c|c|c|c|}
\hline Bank & 2014 & 2015 & 2016 & 2017 & Avg. Value \\
\hline Pashtany Bank & 92.18 & 94.07 & 85.29 & 87.95 & 89.87 \\
\hline New Kabul Bank & 113.78 & 115.66 & 89.23 & 92.10 & 102.69 \\
\hline
\end{tabular}




\begin{tabular}{|c|r|r|r|r|l|}
\hline Bank-e-Millie Afghan & 74.75 & 76.14 & 73.5 & 77.06 & 75.36 \\
\hline Avg. ratio & \multicolumn{4}{|c|}{$\mathbf{8 9 . 3 1}$} \\
\hline
\end{tabular}

Chart 7:-Liquidity Analysis: Customer Deposit to Total Asset Ratio

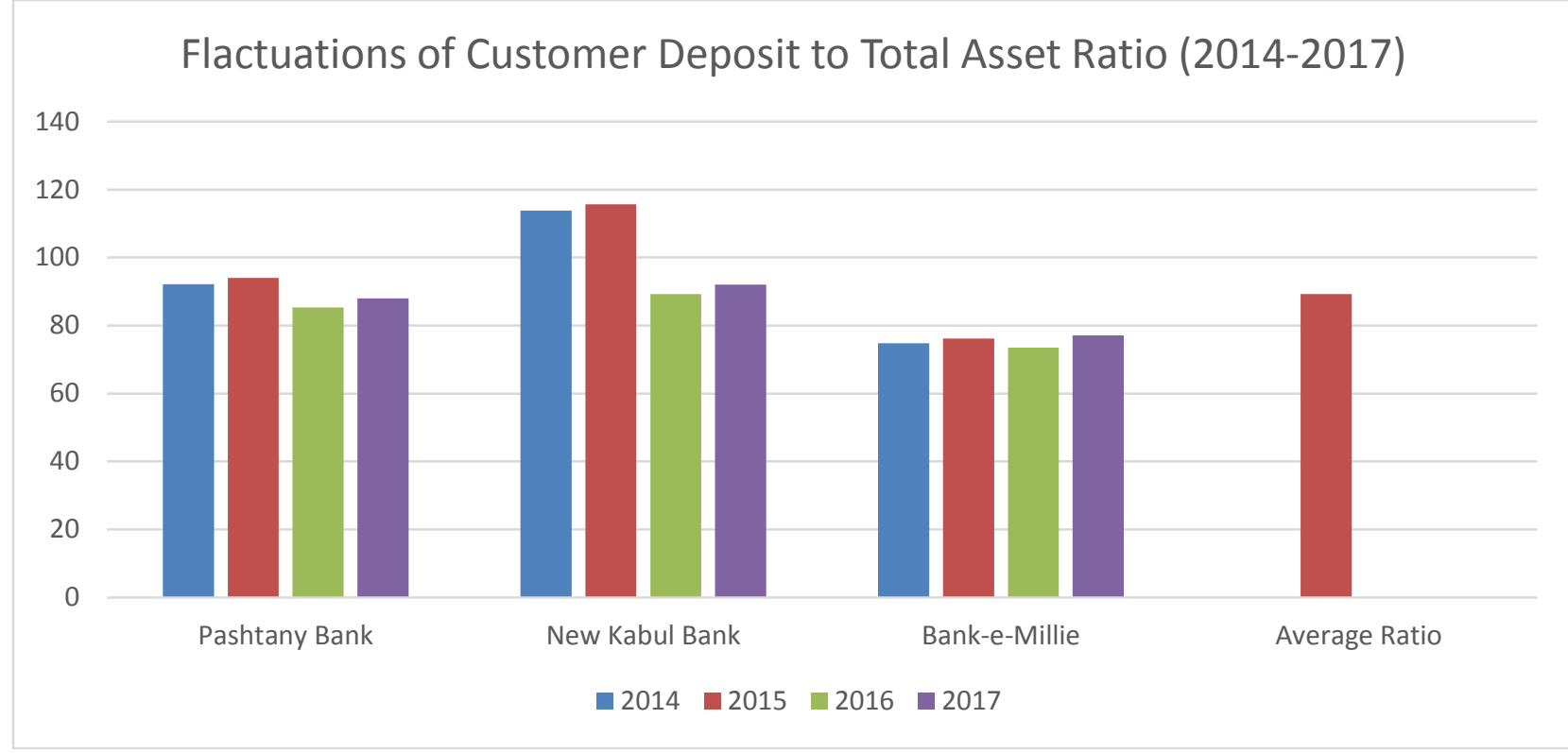

The following table show ranking of banks based on customer deposit to total asset ratio for the period 2014 to 2017.

Table 17:-Banks ranking in terms of Customer Deposit to Total Asset Ratio

\begin{tabular}{|c|c|c|}
\hline Ranks & Bank Name & Avg. Value \\
\hline 1 & New Kabul Bank & 102.69 \\
\hline 2 & Pashtany Bank & 89.87 \\
\hline 3 & Bank-e-Millie Afghan & 75.36 \\
\hline
\end{tabular}

\section{Conclusion:-}

Financial statements of banks are analyzed and interpreted in order to find out financial position and management soundness of the banks. Financial experts have developed many tools and techniques for evaluating financial performance of banking industry and other industries. In this paper, I have used one of most commonly used and effective tools of analyzing financial performance of banks- CAMEL model. CAMEL model investigates financial performance of a bank from different angles, such us, Capital Adequacy, Assets Quality, Management Soundness, Earning Quality and Liquidity.

From the results of data analysis, we can simply rank all the selected banks based on all aspects of CAMEL. Based on Capital Adequacy, Bank-e-Millie Afghan is in first position, Pashtany banks stands second and New Kabul Bank has ranked third positon. Based on Asset Quality, Bank-e-Millie Afghan stands on the top, Pashtany bank and New Kabul bank ranked second and third position respectively. Even on the basis of Management soundness and earning quality, Bank-e-Millie Afghan has got first position, Pashtany Bank and New Kabul Bank has placed second and third places respectively. But, New Kabul bank has got first rank in terms of liquidity analysis. In overall, Bank-eMillie Afghan has high level financial performance among the public sector banks in Afghanistan on the other hand, New Kabul bank is having least and inefficient financial performance.

Finally, the results of the study would be very much helpful for banks management to take better financial decisions and improve financial performance of their respective banks. 


\section{References:-}

1. New Kabul Bank, Financial Statements, https://www.Newkabulbank.af/annual-statement.php. Visited on Feb. 2019

2. New Kabul Bank, Profile, https://www.newkabulbank.af/about.hph. Visited on Feb. 2019

3. Financial Reports, https://pashtanybank.com.af/ visited on Apr 2019

4. Financial Statements, https://www.bma.com.af/about-bma?id=4 visited on Apr 2019

5. Medhat Tarawneh (2006), "A comparison of Financial Performance in Banking Sector: Some Evidence From Omani Commercial Banks", International Research Journal of Finance and Economics, Issue 3

6. Palamalai Srinivasan*, John Britto (2017), "Analysis of Financial Performance of Selected Commercial Banks in India", Theoretical Economics Letters, 2017, 7, 2134-2151

7. Malihe Rostami (2015), "CAMELS' Analysis in Banking Industry", Global Journal of Engineering Science and Research Management,

8. Jeevan Jayant Nagarkar, (2015), "Analysis of Financial Performance of Banks in India", Annual Research Journal of Symbiosis Centre for Management Studies, Pune Vol. 3, pp26-37

9. Noor Rahman Tahiri (2018), "Study on Financial Performance of Da Afghanistan Bank 2015 and 2016", Munich Personal RePEc Archive MPRA Paper No. 88477

10. Mustafa Hassan Mohammad (2014), " Evaluating the Financial Performance of Banks Using Financial RatiosA Case Study of Erbil Bank for Investment and Finance" European Journal of Accounting Auditing and Finance Research, Vol. 2 No. 6, pp. 162-177

11. Amalendu Bhunia, Somnath Mukhuti, Gautam Roy (2011), "Financial Performance Analysis-A Case Study", Current Research Journal of Social Sciences 3(3): 269-275, 2011

12. K. P. Venugopala Rao and Farha Ibrahim (2007), "Financial Performance Analysis of Banks- A Study of IDBI Bank", International Journal of Research in IT and Management, Vol. 7 pp 64-72

13. Mabwe Kumbirai and Robert Webb (2010), "A financial Ratio Analysis of Commercial BankPerformance in South Africa", African Review of Economics and Finance, Vol. 2, No. 1, Dec 2010

14. Melaku Alemu and Melaku Aweke (2017), "Financial Performance Analysis of Private Commercial Banks of Ethiopia: CAMEL Rating", International Journal of Scientific and Research Publication, Vol. 7, Issue 10, Oct 2017

15. Dr. M. Selvam (2013), Financial Performance in the Banking Sector: A Study with Special Reference to Kenyan Commercial Banks Using Data Envelopment Analysis (DEA)", The International Journal's Research Journal of Social Science and Management, Vol. 2 No. 9, January 2013

16. Ch. Balaji (2016), "A Comparative Study on Financial Performance of Selected Public and Private Sector Banks in India", Journal of Commerce and Trade, Vol. 11, No. 2, pp-89-96

17. Esmatullah Mohammady (2019), "A Study on Financial Performance of Private and Public Banks in Afghanistan (2014-2017)", Asian Journal of Research in Banking and Finance, Vol. 9, Issue No. 4 (2019), pp8-30. 